\title{
The Salient Factors Influencing the Choice of Food Retail Outlet amongst First Year Students at a Rural-Based Tertiary Institution
}

\author{
Tafadzwa Matiza \\ Olabanji. A. Oni \\ Department of Business Management, University of Limpopo, Turfloop Campus, \\ Private Bag X1106, Sovenga, 0727, South Africa \\ Email: olabanji.oni@ul.ac.za
}

\author{
Doi:10.5901/mjss.2014.v5n20p954
}

\begin{abstract}
The increasing relevance of young consumers as a market segment has resulted in marketers and brand managers alike becoming more interested in the consumer buying behaviour of young people. In the case of the retail sector, the increasing buying power of young consumers has peaked marketers' interest in the young consumer market segment. This paper aimed to survey the salient factors that influence the choices made by students of which food retailer to buy groceries from. As a result the study conveniently sampled $n=217$ first year School of Economics and Management students. The questionnaire was the data generation tool, and was comprised of close-ended questions and a 5-point Likert scale for responses. Data was collated and descriptive statistics generated utilising Microsoft Excel 2010. Significantly, the survey found that students were principally price sensitive and the pricing of goods was the key influencer for students. It also emerged that the influence of the family's buying behaviour with regards to retailer choice was also a significant influence. The paper recommends further studies into the retail buying behaviour of young consumers as this would be important in the strategic management of brands by marketers as well as retailers.
\end{abstract}

Keywords: food retailers, supermarkets, consumer buying behaviour of students, factors influencing food retailer choice

\section{Introduction}

The retail industry is an important service industry in both developed and developing countries. More-so, in countries such as South Africa, the retail sector makes products available when and where consumers need them (Oghojafor, Ladipo \& Nwagwu, 2012). According to Meng, Florkowski, Sarpong, Chinnan and Resurreccion (2014), the growth in the income of consumers, the expansion of retail outlets and changing consumer preferences in developing countries necessitates an examination of the determinants of consumer food retail outlet choice, as the bargaining power of consumers and threat of new entrants put competitive pressure on major food retailers (supermarkets). As Jobber (2009) ascertains, consumer decision making involves not only the choice of product and brand, but the choice of retail outlet from which to acquire the desired product or brand as well. With this in mind research into the shopping habits of consumers and the factors that influence shopper behaviour aids food retailers (supermarkets and grocery shops) and marketers alike in designing effective and efficient strategies (Dibb, Stern \& Wesley, 2002).

Hamilton (2010) observes that young consumers are increasingly becoming valuable to marketers as their purchasing power has experienced significant growth in recent times. Similarly, for food retailers, the young consumer now represents a growing market segment. One such young consumer segment for retailers is students at intuitions of higher learning. There is paucity in literature relating to empirical studies on the factors that influence the buying behaviour of young consumers and in this case students as a market segment for food retailers. It is therefore the endeavour of this study to contribute towards literature relating to students as a market segment. The aim of this study was to empirically ascertain the influencers of supermarket choice amongst $1^{\text {st }}$ year university students at a South African, rural-based tertiary institution. The objectives of this study were to 1 ) investigate the salient influencers of student choice of supermarket; 2) establish the buying power and behaviour of $1^{\text {st }}$ year students in relation to their choice of food retailer (supermarket); 3) determine the relevance of the family unit as a social reference group in their selection of food retailer. In order to achieve the fore-mentioned objectives, the study sought to address the following research questions:

1. What are the salient factors influencing the choice of food retailer amongst the sampled $1^{\text {st }}$ year students?

2. What is the buying behaviour of these $1^{\text {st }}$ year students with particular reference to food retailers? 
3. Of what significance if the family as a social reference group with regards to students' choice of food retail outlet (supermarket) amongst the sampled $1^{\text {st }}$ year students?

\section{Review of Literature}

Consumer behaviour refers to the study of individuals, groups or organisations and the process they use to select, secure and dispose of products, services, experiences or ideas to satisfy needs and the impacts that these processes have on the consumer and society (Hawkins, Best \& Coney, 2001). According to Babin and Harris (2011), the factors that affect consumer behaviour can be classified into two main categories, internal and external, with the external factors being relevant to this study. These external factors include store-related and retail environment related variables, which make up what may be referred to as external influencers. There is extensive literature on the factors influencing consumer behaviour with regards to the selection of food retailer (supermarkets \& grocery stores). Table 1 summarises the key influencers based on various empirical studies:

Table1: Summary of Influencers of Food Retailer Choice

\begin{tabular}{|l|l|}
\hline \multicolumn{1}{|c|}{ Author } & \multicolumn{1}{c|}{ Influencers Identified } \\
\hline Uslu (2005) & $\begin{array}{l}\text { Store staff approach to consumers, contents of products, parking space, issues of hygiene, variety of } \\
\text { products, product price, location convenience and product quality. }\end{array}$ \\
\hline $\begin{array}{l}\text { Sinha \& Banerjee } \\
(2004)\end{array}$ & $\begin{array}{l}\text { Store convenience and customer services positively influence customers' supermarket choices, whilst } \\
\text { entertainment, parking and ambiance facilities had a negative influence on consumer outlet choice. }\end{array}$ \\
\hline $\begin{array}{l}\text { Miranda, Kaya \& } \\
\text { Havrila (2005) }\end{array}$ & $\begin{array}{l}\text { Location of store, nature and quality of stocks, in-store-promotions, sales personnel, physical attribute, } \\
\text { convenience of store, atmosphere and loyalty cards. }\end{array}$ \\
\hline $\begin{array}{l}\text { Polat \& Kutlers } \\
(2007)\end{array}$ & $\begin{array}{l}\text { Product diversity, product quality, inner atmosphere \& appearance, quick shopping facility, attitude and } \\
\text { interest of staff and prices of goods. }\end{array}$ \\
\hline $\begin{array}{l}\text { Duman \& Yagci } \\
(2006)\end{array}$ & $\begin{array}{l}\text { Patronage intentions are affected by value perception, product quality perception, service quality } \\
\text { perception, discount perception and comparable price perception. }\end{array}$ \\
\hline
\end{tabular}

Source: Oghojafore, Ladipo \& Nwagwu (2012)

Literature also identifies several salient influencers in retailer choice. Cox and Brittain (1996) found that there are certain expectations of retailers from consumers and these include a convenient location for consumers to access goods and services, an assortment of appropriate merchandise, break bulk services, services to effect change of ownership (purchasing) and holding stock for instant availability to consumers at relatively stable and reasonable prices. Kursunluoglu (2014) establishes 5 criteria that affect consumers' supermarket choices as; 1) reliability of the supermarket; 2) short waiting period on check-out lines; 3) correctness of the price tags on the shelves; 4) broad merchandise assortment, and; 5) impressive in-store atmosphere. A study by Batt (2009) on Australian consumers ranked influencers of supermarket choice as follows; 1) competitive price; 2) good quality products; 3) freshness; 4)convenience; 5)close proximity to home and; 6) location. While, a study based on Malaysian consumers by Wel, Husssain, Omar and Nor (2012) ranked influences as follows; 1) store personnel and physical characteristics; 2) adversity by the store; 3) store merchandise selection; 4) store location; 5) peer influence; 6) product variety and quality; 7) services offered by the store.

The literature reviewed in this section has highlighted some of the salient factors that influence the consumer behaviour in the selection food retailer (supermarket/grocery shop). These influencers were adapted to inform the survey questions utilised to generate the empirical data for the study.

\section{Methodology}

With the aim and objectives of this study in mind, the quantitative approach to research is prudent. The data required for this study is descriptive in nature and the quantitative paradigm focuses on the generation and measurement of numbers and statistics. The sample population for this study was a convenient sample of $n=2171^{\text {st }}$ year students in the School of Economics and Management at the University of Limpopo's Turfloop campus (South Africa). Non-probability sampling was adequate for the purposes of this study since these students were easily accessible and represented a cross-section of different backgrounds and met the requirements of the study of gathering data on the factors influencing their choice of supermarket when they do their grocery shopping. 
Data was collected utilising the survey approach, with data being collected by the questionnaire tool which was primarily made up of 5-point Likert-Scale response to questions ranging from Not Influential to Extremely Influential (Vagias, 2006). Self-administered questionnaires were deployed to the students and questionnaires were collected and checked before being collated in Microsoft Excel 2010 spreadsheet. Simple descriptive statistics (frequencies \& cumulative frequencies) and graphs were generated utilising this program.

\section{Results}

The following are the results of the survey conducted:

\subsection{Demographics}

Table 2 summarises the key demographic data of the students surveyed in the study. The majority of the students surveyed $(55.30 \%)$ were female, while the minority (44.70\%) were male. The bulk of the $1^{\text {styear }}$ students surveyed (77.42\%) were aged between 16 to 20 years of age. While, $15.7 \%, 5.53 \%$ and $1.38 \%$ of the students were aged between 21 to 25,26 to 30 , and over 30 years of age respectively.

Table 2: Summary of Demographic Information

\begin{tabular}{|c|c|c|c|c|c|c|c|c|c|c|}
\hline & & & & & & & & \\
\hline Demographics & $f$ & $\begin{array}{c}\text { Cum } \% \text { Freq } \\
n=217\end{array}$ & & & & & & & & \\
\hline Male & \begin{tabular}{|l|}
97 \\
\end{tabular} & 44.70 & & & & & & & & \\
\hline Female & 120 & 55.30 & & & & & & & & \\
\hline Total & 217 & 100 & & & & & & & & \\
\hline \multirow[t]{2}{*}{ Age } & \multicolumn{2}{|r|}{$\overline{16-20}$} & \multicolumn{2}{|r|}{$21-25$} & \multicolumn{2}{|r|}{$26-30$} & \multicolumn{2}{|r|}{$>30$} & & \\
\hline & $f$ & $\begin{array}{c}\text { Cum } \% \text { Freq } \\
n=217\end{array}$ & $f$ & $\begin{array}{c}\text { Cum } \% \text { Freq } \\
n=217\end{array}$ & $f$ & $\begin{array}{c}\text { Cum } \% \text { Freq } \\
n=217\end{array}$ & $f$ & $\begin{array}{c}\text { Cum } \% \text { Freq } \\
n=217\end{array}$ & & \\
\hline Student Age Distribution & 168 & 77.42 & 34 & 15.67 & 12 & 5.53 & 3 & 1.38 & & \\
\hline \multirow[t]{2}{*}{ Spending Power } & \multicolumn{2}{|r|}{$>\mathrm{R} 200$} & \multicolumn{2}{|r|}{ R201-R500 } & \multicolumn{2}{|r|}{ R501-R800 } & \multicolumn{2}{|r|}{$>\mathrm{R} 800$} & & \\
\hline & $f$ & $\begin{array}{c}\text { Cum } \% \text { Freq } \\
n=217\end{array}$ & $f$ & $\begin{array}{c}\text { Cum } \% \text { Freq } \\
n=217\end{array}$ & $f$ & $\begin{array}{c}\text { Cum } \% \text { Freq } \\
n=217\end{array}$ & $f$ & $\begin{array}{c}\text { Cum } \% \text { Freq } \\
n=217\end{array}$ & $\begin{array}{c}\text { Total } \\
n=217\end{array}$ & $\begin{array}{c}\text { Cum } \% \text { Freq } \\
n=217\end{array}$ \\
\hline Monthly Spend on Groceries & 17 & 7.83 & 94 & 43.32 & 83 & 38.25 & 23 & 10.60 & 217 & 100 \\
\hline \multirow[t]{2}{*}{ Frequency of Shopping } & \multicolumn{2}{|c|}{ Once a week } & \multicolumn{2}{|c|}{$\begin{array}{c}\text { More than once a } \\
\text { week }\end{array}$} & \multicolumn{2}{|c|}{ Every other week } & \multicolumn{2}{|c|}{ Almost Never } & & \\
\hline & $f$ & $\begin{array}{c}\text { Cum } \% \text { Freq } \\
n=217\end{array}$ & $f$ & $\begin{array}{c}\text { Cum } \% \text { Freq } \\
n=217\end{array}$ & $f$ & $\begin{array}{c}\text { Cum } \% \text { Freq } \\
n=217\end{array}$ & $f$ & $\begin{array}{c}\text { Cum } \% \text { Freq } \\
n=217\end{array}$ & $\begin{array}{c}\text { Total } \\
n=217\end{array}$ & $\begin{array}{c}\text { Cum } \% \text { Freq } \\
n=217\end{array}$ \\
\hline Supermarket visits per month & 61 & 28.11 & 38 & 1751 & 109 & 50.23 & 9 & 4.15 & 217 & 100 \\
\hline
\end{tabular}

\section{Source: Field Data}

Other relevant demographic information collected during the survey was related to the spending power and buying behaviour of the students. As a result of the survey it emerged that the bulk of the students sampled (43.32\%) had a buying power of between R201 and R500 a month for groceries, while 38.25\% had between R501 and R800 per month, $10.60 \%$ had more than R800 a month to spend on groceries and $7.83 \%$ had less than R200 per month to spend on groceries. With regards to the buying behaviour of the students it emerged from the sample that, the majority of respondents (50.23\%) visited a food retailer every other week, while $28.11 \%$ visited a food retailer once a week, $17.51 \%$ more than once a week and $4.15 \%$ almost never. 
Table 3: Summary of influencers of food retailer outlet choice

\begin{tabular}{|c|c|c|c|c|c|c|c|c|c|c|c|c|}
\hline Factor & & $\mathrm{NI}$ & & SI & & SWI & & VI & & EI & & \\
\hline & $f$ & $\begin{array}{c}\text { Cum } \% \text { Freq } \\
N=217\end{array}$ & $f$ & $\begin{array}{c}\text { Cum } \% \text { Freq } \\
N=217\end{array}$ & $f$ & $\begin{array}{c}\text { Cum } \% \text { Freq } \\
\qquad=217\end{array}$ & $f$ & $\begin{array}{c}\text { Cum } \% \text { Freq } \\
N=217\end{array}$ & $f$ & $\begin{array}{c}\text { Cum } \% \text { Freq } \\
N=217\end{array}$ & Total Cum N & $\begin{array}{l}\text { Total } \\
\text { Cum \% }\end{array}$ \\
\hline \begin{tabular}{|l|} 
Pricing of products \\
\end{tabular} & 3 & 1.38 & 7 & 3.23 & 19 & 8.76 & 61 & 28.11 & 127 & 58.53 & 217 & 100.00 \\
\hline Discounts \& Promotions & 33 & 15.21 & 67 & 30.88 & 28 & 12.90 & 38 & 17.51 & 51 & 23.50 & 217 & 100.00 \\
\hline $\begin{array}{l}\text { Convenience of location of } \\
\text { Supermarket }\end{array}$ & 10 & 4.61 & 9 & 4.15 & 21 & 9.68 & 31 & 14.29 & 146 & 67.28 & 217 & 100.00 \\
\hline Scale of products offered & 26 & 11.98 & 24 & 11.06 & 32 & 14.75 & 42 & 19.35 & 93 & 42.86 & 217 & 100.00 \\
\hline Quality of goods on offer & 13 & 5.99 & 38 & 17.51 & 51 & 23.50 & 27 & 12.44 & 88 & 40.55 & 217 & 100.00 \\
\hline $\begin{array}{l}\text { Shopping environment } \\
\text { (cleanliness; set-up) }\end{array}$ & 24 & 11.06 & 69 & 31.80 & 81 & 37.33 & 11 & 5.07 & 32 & 14.75 & 217 & 100.00 \\
\hline $\begin{array}{l}\text { Shopping aids (baskets; } \\
\text { trolleys; shop assistants) }\end{array}$ & 64 & 29.49 & 75 & 34.56 & 36 & 16.59 & 23 & 10.60 & 19 & 8.76 & 217 & 100.00 \\
\hline $\begin{array}{l}\text { Customer Service (time spent } \\
\text { at till-point) }\end{array}$ & 3 & 1.38 & 14 & 6.45 & 38 & 17.51 & 68 & 31.34 & 94 & 43.32 & 217 & 100.00 \\
\hline Parking Space & 173 & 79.72 & 34 & 15.67 & 10 & 4.61 & 0 & 0.00 & 0 & 0.00 & 217 & 100.00 \\
\hline
\end{tabular}

Key: NI=Not at all Influential; SI=Slightly Influential; Somewhat Influential; VI=Very Influential; El=Extremely Influential

\subsection{Factors Influencing student choice of food retailer}

Table 3 summarises the descriptive statistics of the data collected during the survey with regards to the factors influencing food retailer choice amongst the $1^{\text {st }}$ year students surveyed.

As a result of the survey it emerged that the pricing of products was extremely influential in the selection of food retailer by students, with $58.53 \%$ of students identifying it as such. $28.11 \%$ of students identified pricing as being very influential, with $8.76 \%, 3.23 \%$ and $1.38 \%$ of students responding that pricing of products was some-what influential, slightly influential and not influential respectively. Discounts and promotions on products as it emerged has a slight influence (30.88\%) on student choice of food retailer, while $23.50 \% 17.51 \%, 12.90 \%$ and $15.21 \%$ were of the opinion that discounts and promotions were extremely influential, very influential, some-what influential and not influential respectively. The convenience of the location food retail outlet (supermarket/grocery shop) is as it emerged extremely influential (67.28\%) on student choice of outlet. While, $14.29 \%, 9.68 \%, 4.61 \%$ and $4.15 \%$ of the $1^{\text {st }}$ year students surveyed felt that the location convenience of the retailer was very influential, some-what influential, not influential and slightly influential respectively. The scale of the products offered by the retailer is as it emerged extremely influential (42.86\%). While, $19.35 \%$ of students determined that the scale of products on offer was very influential in their choice of retailer. At the same time, $14.75 \%$ of students believed it to be some-what influential, while $11.98 \%$ and $11.06 \%$ of students believed the scale of products on offer to not be influential and slightly influential respectively.

Product quality was also found to be extremely influential to student choice, with $40.55 \%$ of students being of that opinion. $23.50 \%$ of students were of the opinion that product quality was some-what influential in their choice of retailer, while, $17.51 \%, 12.44 \%$ and $5.99 \%$ of students indicated that the quality of goods on offer from the retailer was slightly influential, very influential and not influential respectively. The shopping environment within the retail outlet was found to be some-what influential (37.33\%), with $31.80 \%$ of students found the shopping environment to be slightly influential. $14.75 \%, 11.06 \%$ and $5.07 \%$ of the students surveyed indicated that the shopping environment was extremely influential, not influential and very influential respectively. It also emerged during the survey that shopping aids were slightly influential (34.56\%) in student's decisions when selecting food retailer. $29.49 \%$ of students were of the opinion that the availability of shopping aids was not influential at all. $16.59 \%, 10.60 \%$ and $8.76 \%$ of students felt that shopping aids were some-what influential, very influential and extremely influential respectively. Customer service as it emerged is extremely influential to $43.32 \%$ of the students surveyed, while $31.34 \%$ of the students specified that customer service was very influential in their choice. $17.51 \%, 6.45 \%$ and $1.38 \%$ of students pointed out that customer service was some-what influential, slightly influential and not at all influential respectively. Parking space is not influential in students' selection of food retailer, with $79.72 \%$ of students indicating as such. $15.67 \%$ of students indicated that parking space was slightly influential and $4.61 \%$ identified parking space as a some-what influential factor when considering their choice of retailer (supermarket of grocery shop). None of the students surveyed considered parking space to be neither very influential nor extremely influential in their decision making process. 


\subsection{The family as a reference group}

Students were specifically asked how influential their family shopping preferences were on their individual choice of supermarket. Table 4 summarises the responses of the surveyed students.

Table 4: The family as a reference group

\begin{tabular}{|c|c|c|c|c|c|c|c|c|c|c|c|c|}
\hline & & $\mathrm{NI}$ & & SI & & SWI & & VI & & El & & \\
\hline & $f$ & $\begin{array}{c}\text { Cum } \% \\
\text { Freq } \\
N=217\end{array}$ & $f$ & $\begin{array}{c}\text { Cum } \% \\
\text { Freq } \\
N=217\end{array}$ & $f$ & $\begin{array}{c}\text { Cum \% } \\
\text { Freq } \\
N=217\end{array}$ & $f$ & $\begin{array}{c}\text { Cum \% } \\
\text { Freq } \\
N=217\end{array}$ & $f$ & $\begin{array}{c}\text { Cum } \% \\
\text { Freq } \\
N=217\end{array}$ & Total Cum $\mathbf{N}$ & $\begin{array}{c}\text { Total } \\
\text { Cum } \%\end{array}$ \\
\hline $\begin{array}{l}\text { Influence of where parents/guardians shop } \\
\text { for the family on your choice of } \\
\text { supermarket }\end{array}$ & 4 & 1.84 & 23 & 10.60 & 85 & 39.17 & 74 & 34.10 & 31 & 14.29 & 217 & 100.00 \\
\hline
\end{tabular}

Key: NI=Not at all Influential; SI=Slightly Influential; Somewhat Influential; VI=Very Influential; El=Extremely Influential

The results suggest that the choice of food retailer amongst students is some-what influenced (39.17\%) by the choices of their family unit. While, $34.10 \%$ of students indicated that the consumer buyer behaviour of their family as a reference group was very influential in their choice of food retail outlet. $14.29 \%, 10.60 \%$ and $1.84 \%$ of the students surveyed indicated that their family as a reference group was extremely influential, slightly influential and not influential respectively.

\subsection{Key Influencer amongst students}

Finally students were asked to select one key factor they considered to be the most influential in their choice of food retail outlet. Figure 1 illustrates the findings of the survey.

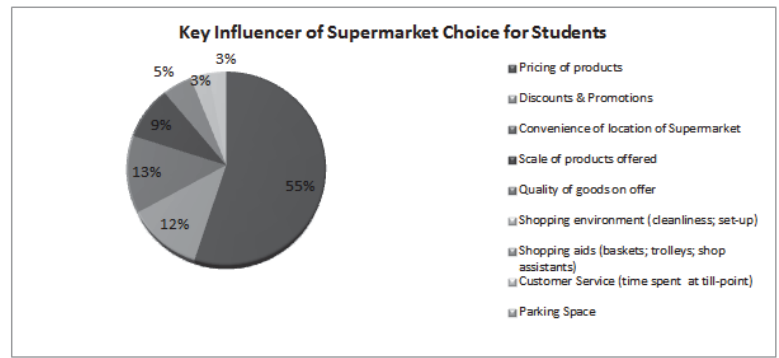

Figure 1: Key Influencer of Supermarket Choice amongst Students

As a result of the survey it emerged that amongst the sampled $1^{\text {st }}$ year students the key influencers can be ranked as follows; 1) Pricing of products (55\%), 2) Convenience of location of the supermarket (13\%), 3) Discounts and Promotions $(12 \%), 4)$ Scale of products offered by the retailer $(9 \%), 5$ ) Quality of goods on offer (5\%), 6) Shopping environment (3\%) and Customer service (3\%) and 7) Shopping aids (0\%) and parking space (0\%).

\section{Discussion \& Conclusion}

The survey was primarily aimed at identifying which salient factors influence the choice of food retailer (supermarket) amongst a young market segment of $1^{\text {st }}$ year students currently enrolled at a rural-based institution of higher learning. As it emerged, the students sampled for this study had an average buying power of between R200 and R800 for groceries per month, with the average student purchasing their requirements every other week. Importantly, the study established that the pricing of products, convenience of location of the retail outlet (supermarket), scale and quality of products on offer, as well as customer service were extremely influential in their choice of retailer. On the other end of the scale, parking space was deemed to be the not influential in their decision making process. The findings of this study are consistent with existing literature (Duman \& Yagci, 2006; Batt, 2009).

Significantly the study found that the shopping habits of the family as a reference group had a some-what to very 
influential effect on the consumer buying behaviour of the surveyed students. This is consistent with the ascertain by Wiese (2004) that the family is probably the most important primary reference group in the formation of buying behaviour. However, Wiese (2004) does caution that although the parental role in brand selection has a diminution effect, there is a widely held belief that brands (products and services) that are preferred by the family will continue to be purchased by the children once they become adults.

As a result of this study this paper concludes that students are particularly price sensitive, and that the prices of the goods on offer from the retailer are a key influencer of food retailer choice amongst students. As a result of this survey this paper also concludes that students have a relatively average to high buying power and sustained buying behaviour with regards to the purchase of grocery products and form an important market segment for retailers, particularly those located conveniently in the vicinity of tertiary institutions. Finally this paper concludes that the family unit is a significant reference group for young consumers, particularly in the selection of food retailer (supermarket). Further studies into the consumer buying behaviour of young consumers in this and other retail sectors (clothing, mobile networks) are recommended. Such research would be beneficial to marketers and brand managers in their market segmentation and positioning strategies, with very lucrative long-term competitive advantage and brand loyalty being the strategic outcome.

\section{References}

Babin, B.J. \& Harris, E.C. (2011). Consumer Behaviour, 3rd Ed. Ohio: South-Western Cengage Lessing.

Bates, J.M. \& Gabor, A. (1987). Changes in subjective welfare and purchase behaviour: A report on enquiry. Journal of Marketing Research Society, 29(2), pp183-207.

Batt, P.J. (2009). Factors influencing the consumer's choice of retail store. Curtin Business School, Curtin University of Technology, Australia.

Cox, R. \& Brittain, P. (1996). Retail Management, 3rd Ed. Hong Kong: Pitman Publishing.

Dibb, S, Stern, P. Wensley, R. (2002). Marketing knowledge and the value of segmentation. Marketing Intelligence and Planning, 20(2), pp113-119.

Duman, T \& Yagci, M.I. (2006). On factors affecting consumer's purchase intentions of supermarket customers: An attempt at modelling. METU Studies Development, 33, pp87-116.

Engel, J. P, Blackwell, R.D. \& Miniard, P.W. (1995). Consumer Behaviour, $8^{\text {th }}$ Ed. Orlando: Dryden press.

Euromonitor (1986). The changing face of grocery retailing. Euromonitor: London.

Hamilton, I. (2010). The influence of culture on students' impulsive buying behaviour in the Vaal Triangle. Master of Commerce Thesis in Business Management. North West University, South Africa.

Hawkins, D.I, Best, R.J. \& Coney, K.A. (2001). Consumer Behaviour: Building Marketing Strategy, 8th Ed. New York: McGraw-Hill.

Jobber, D. (2009). Principles and practice of marketing. England: McGraw-Hill Publishing Company.

Jones, M.A. \& Rynolds, K.E. (2006). The role of outlet on shopping behaviour. Journal of Retailing, 12, 115-126.

Kumar, M. Singh, N. (2012). A study of diversity in retail purchases behaviour in food and grocery in NCR (Noida \& Ghaziabad): An aid to formulate retail strategy. Maharaja Agrasen Institute of Management and Technology. Journal of Information Technology \& Management, Kapurathala, 5(2), pp1-18.

Kursunluoglu, E. (2014). The criteria that influence consumers' supermarket choices. International Conference on Business, Economics \& Management. Yasar University, Izmin, Turkey.

Meng, T, Florkowski,W.J, Sarpong, D.B, Chinnan, M.S. \& Resurreccion, A.V.A. (2014). Consumer's food shopping choice in Ghana: Supermarket or traditional outlets? International Food \& Agribusiness Management Review, 17(A), pp107-129.

Miranda, M, Kaya, L. \& Havrila, I. (2005). Shoppers' satisfaction levels are not the only key to store loyalty. Marketing Intelligence \& Planning, 23, pp220-232.

Muzondo N. \& Mutandwa, E. (2011). The seven P's of marketing and choice of main grocery store in a hyper-inflationary economy. Contemporary Marketing Review, 1(9), pp1-18.

Oghojafor, B.E.A, Lapido, P.K.A \& Nwagwu, K.O. (2012). Outlet attributes as determinants of preference of women between a supermarket and a traditional open market. American Journal of Business \& Management, 1(4), 230-240.

Polat, C \& Kutler, B. (2007). The factors that affect the retail store preferences of customers: An application on the consumers in Nigde. $12^{\text {th }}$ National marketing Conference, Sakanya, Turkey.

Sinha, P.K. \& Banerjee, A. (2004). Store choice behaviour in an evolving market. International Journal of Retail Distribution Management, 32(10), pp482-494.

Uslu, S. (2005). The reasons that shopping mall preferences of consumers. Marketing World, 19, 54-63.

Vagias, W.M. (2006). Likert-type scale response anchors. Clemson International Institute for Tourism \& Research Development. Department of Parks, Recreation \& Tourism Management. Clemson University.

Wel, C.A.C, Hussin, S.R, Omar, N.A. \& Nor, S.M. (2012). Important determinant of consumers' retail selection decision in Malaysia. World Review of Business Research, 2(2), pp164-175.

Wiese, M. (2004). Consumer preferences and buying patterns of students at Tshwane University of Technology, Witbank Campus. Master of Technology in Marketing. Tshwane University of Technology. 